\title{
Article \\ A New Approach to Assessing the Energy Efficiency of Industrial Facilities
}

\author{
Natalia Verstina, Natalia Solopova (D), Natalia Taskaeva, Tatiana Meshcheryakova * and Natalia Shchepkina $\mathbb{D}$
}

Citation: Verstina, N.; Solopova, N Taskaeva, N.; Meshcheryakova, T.; Shchepkina, N. A New Approach to Assessing the Energy Efficiency of Industrial Facilities. Buildings 2022, 12, 191. https://doi.org/10.3390/ buildings12020191

Academic Editors: Roberto Alonso González Lezcano, Francesco Nocera and Rosa Giuseppina Caponetto

Received: 8 January 2022

Accepted: 4 February 2022

Published: 8 February 2022

Publisher's Note: MDPI stays neutral with regard to jurisdictional claims in published maps and institutional affiliations.

Copyright: (C) 2022 by the authors. Licensee MDPI, Basel, Switzerland. This article is an open access article distributed under the terms and conditions of the Creative Commons Attribution (CC BY) license (https:// creativecommons.org/licenses/by/ $4.0 /)$.
Department of Management and Innovation, Moscow State University of Civil Engineering (National Research University), Yaroslavskoe Shosse 26, 129337 Moscow, Russia; verstinang@mgsu.ru (N.V.); solopovana@mgsu.ru (N.S.); taskayevann@mgsu.ru (N.T.); schepkinann@mgsu.ru (N.S.)

* Correspondence: meshcheryakovats@mgsu.ru

Abstract: The modern climate policy of different countries, decarbonization, the principles of ESG and sustainable development determine the main trends in the world economy, the result of which is a new vision of the energy-saving problem. The authors' research is based on the key idea that in the modern world, systematic measures are needed to improve the energy efficiency of enterprises in the industrial sector of the economy. The article analyzes the systems used for assessing the energy efficiency of objects for various purposes, and on this basis, their advantages and limitations in application are revealed, which were taken by the authors as a basis for developing a new approach to assessing the energy efficiency of industrial facilities. The study gives preference to the point-rating assessment. The authors have developed a system of indicators structured by groups: building energy efficiency, technological process energy efficiency, energy efficiency and environmental friendliness management. The system of indicators of energy efficiency of an industrial facility proposed by the authors has been replaced as a basis for ranking industrial facilities by energy efficiency classes.

Keywords: energy efficiency; energy saving; sustainable development; ESG principles; industrial facility; energy efficiency indicators

\section{Introduction}

The modern climate policy of states and decarbonization is currently supported by a number of steps that are being implemented both in individual countries and at the intergovernmental level. Climatic degradation caused by anthropogenic greenhouse gas (GHG) emissions is noted in the paradigms of not only ecological but also energy and economic development of industrialized countries. This encourages states to constantly work to improve international and national so-called "green" standards for various sectors of the economy, including for its industrial sector.

In December 2019, the EU declared a "green course", the goal of which is to achieve climate neutrality by 2050. Scientists and experts consider carbon neutrality as a set of actions aimed at reducing the carbon footprint at all stages of the product life cycle, "intermediate" targets for the way to which will be the reduction in 2030 of $\mathrm{CO}_{2}$ emissions by $55 \%$ to the level of 1990 and an increase in the share of renewable energy sources in the energy balance of countries to $38-40 \%$ (in electricity-up to $65 \%$ ). At the same time, after 10 years, the EU expects, primarily at the expense of the industrial sector of the economy, to reduce the consumption of coal by $70 \%$ and oil and gas by $30 \%$ and $25 \%$ compared to 2015 , respectively. In parallel with the EU, similar practical steps are being taken in Asia and North America. Therefore, in September 2020, China announced carbon neutrality by 2060, and from 1 February 2021, the country introduced a national emissions trading system. In October 2020, Japan and South Korea made statements of achieving carbon neutrality by 2050. The United States plans to sign the Paris Agreement and continue the environmental course of development of the industrial and energy sectors of the economy [1-3]. 
In the above context, the principles of ESG (environmental-ecology, social-social development, governance-corporate governance), which are also called the principles of responsible investment, are becoming more widespread. Both industrialized countries and companies in the industrial sector of the economy are evaluated according to the ESG (World Energy Trilemma Index) index. According to the British audit and consulting company Ernst \& Young Global Limited, 97\% of investors today are guided by the ESG index, making a decision when choosing an investment object, the provision of high values of which is relevant for all enterprises in the industrial sector of the economy, the problematic part of the activity, in this case, is the improvement of environmental indicators directly related to the energy efficiency of their activities [4,5]. The catalyst for compliance with ESG principles, including environmental friendliness, is the organization of an effective system for monitoring energy consumption and managing energy costs of enterprises in the industrial sector of the economy, focused on reducing them and increasing the energy efficiency of industrial facilities. In view of this, the system for assessing the energy efficiency of industrial facilities is of particular importance, the importance of which in the considered context is increasing.

Let us note another important condition for ensuring energy efficiency of all enterprises in the industrial sector of the economy: the need to revise approaches to assessing their energy efficiency is caused by the instability of the world economy in the context of a pandemic. COVID-19 in 2020 affected the change in the volume of energy consumption in the world, which decreased by 4\%. Moreover, in the period from 2000 to 2018. This average annual rate was $2 \%$, and in 2019 fell to $0.8 \%$ [6]. In 2020, energy consumption decreased in most countries due to the introduced lockdowns, which affected the activities of enterprises in the industrial sector of the economy in almost all sectors of the economy.

It is obvious that the restoration by enterprises of the industrial sector of the production economy to the "pre-pandemic" level and its further increase after the localization of the pandemic will lead to an increase in energy consumption. It will affect the consumption of fossil fuels, which are currently the main sources of energy for enterprises in the industrial sector of the economy. Such data are based on the dominance in the global energy balance of fossil fuels according to world expert forecasts, despite the most positive forecasts for the development of renewable energy sources. A logical consequence will be an increase in the volume of emissions of pollutants and greenhouse gases, which should be taken under special control at the level of each enterprise in the industrial sector of the economy, first of all, by managing its energy consumption.

In this regard, in the study, the authors focused their attention on enterprises in the industrial sector of the economy as the largest end consumers of energy resources [6]. In the course of the research, the problem of defining a previously not specified concept of the category of "industrial object" was identified, the study of the definitions of which showed the presence of discrepancies and blurred formulations, which became a system-forming task of the study.

The subject of the study is the assessment of the energy efficiency of an industrial facility that characterizes the problem area of the study. The aim of the study is to form a new approach to assess the energy efficiency of industrial facilities, which makes it possible to significantly unify the monitoring of energy consumption at enterprises of the industrial sector of the economy, and on this basis, to ensure the possibility of accelerating their transition to ESG principles and focusing them on the need to form new management tools to improve environmental performance directly related to the energy efficiency of their activities. For the set goal, the corresponding tasks were constructed and solved, the achievements of the consistent solution of which are associated with new scientific results:

- to specify the category "industrial facility" as an object of energy efficiency assessment;

- to determine the factors for assessing the energy efficiency of an industrial facility;

- form a system of indicators for assessing the energy efficiency of industrial facilities;

- develop a formula for calculating energy efficiency indicators of an industrial facility. 
The solution to the tasks was carried out in three consecutive stages, which are presented in Table 1.

The first stage, research of information systems, is aimed at systematizing and analyzing the current regulatory and legislative framework, using terms and approaches to assess the energy efficiency of objects for various purposes, relevant for the development of a new approach to assessing the energy efficiency of industrial facilities.

Table 1. Problem-solving logic.

\begin{tabular}{|c|c|c|c|}
\hline \multirow[b]{2}{*}{ Tasks } & Stage 1 & Stage 2 & Stage 3 \\
\hline & $\begin{array}{l}\text { Research of Public } \\
\text { Information Sources }\end{array}$ & $\begin{array}{l}\text { Organization of an Expert } \\
\text { Survey on the Assessment of } \\
\text { the Energy Efficiency } \\
\text { of an Industrial Facility }\end{array}$ & $\begin{array}{l}\text { Formation of a System of } \\
\text { Indicators } \\
\text { for Assessing } \\
\text { the Energy Efficiency of an } \\
\text { Industrial Facility }\end{array}$ \\
\hline \multirow{3}{*}{$\begin{array}{l}\text { 1. Specify "industrial facility" } \\
\text { as an object of energy } \\
\text { efficiency assessment }\end{array}$} & $\begin{array}{l}\text { Systematization: } \\
\begin{array}{l}\text { - } \\
\text { regulatory and } \\
\text { legislative framework } \\
\text { for assessing the energy } \\
\text { efficiency of objects for } \\
\text { various purposes; }\end{array}\end{array}$ & $\begin{array}{l}\text { Conducting an expert survey } \\
\text { on the topic of the study, } \\
\text { taking into account the issue } \\
\text { of clarifying the concept of } \\
\text { "industrial facility". }\end{array}$ & \\
\hline & $\begin{array}{l}\text { - } \quad \text { terms in the field of } \\
\text { energy efficiency; } \\
\text { - } \\
\text { approaches to the } \\
\text { definition of an energy } \\
\text { efficiency object; } \\
-\quad \text { existing national and } \\
\text { international systems for } \\
\text { assessing the energy } \\
\text { efficiency of various } \\
\text { facilities. }\end{array}$ & $\begin{array}{l}\text { Consolidation of survey data, } \\
\text { processing and interpretation } \\
\text { of expert survey results. } \\
\text { Clarification of the concept of } \\
\text { "industrial facility". }\end{array}$ & \\
\hline & $\begin{array}{l}\text { Definition: } \\
\text { - } \quad \text { object of energy } \\
\text { efficiency assessment; } \\
-\quad \text { indicators of } \\
\text { consumption of energy } \\
\text { resources when } \\
\text { assessing the energy } \\
\text { efficiency of the facility. }\end{array}$ & & \\
\hline $\begin{array}{l}\text { 2. Formulate factors for } \\
\text { assessing the energy efficiency } \\
\text { of an industrial facility }\end{array}$ & $\begin{array}{l}\text { Systematization of factors } \\
\text { affecting the energy efficiency } \\
\text { of buildings. } \\
\text { Systematization of factors } \\
\text { affecting the energy efficiency } \\
\text { of technological processes. }\end{array}$ & $\begin{array}{l}\text { Systematization of expert } \\
\text { opinions on the importance of } \\
\text { factors affecting the energy } \\
\text { efficiency of an industrial } \\
\text { facility. } \\
\text { Identification of factors } \\
\text { affecting the energy efficiency } \\
\text { of an industrial facility. }\end{array}$ & Consideration of factors. \\
\hline
\end{tabular}


Table 1. Cont.

\begin{tabular}{|c|c|c|c|}
\hline \multirow[b]{2}{*}{ Tasks } & Stage 1 & Stage 2 & Stage 3 \\
\hline & $\begin{array}{l}\text { Research of Public } \\
\text { Information Sources }\end{array}$ & $\begin{array}{l}\text { Organization of an Expert } \\
\text { Survey on the Assessment of } \\
\text { the Energy Efficiency } \\
\text { of an Industrial Facility }\end{array}$ & $\begin{array}{l}\text { Formation of a System of } \\
\text { Indicators } \\
\text { for Assessing } \\
\text { the Energy Efficiency of an } \\
\text { Industrial Facility }\end{array}$ \\
\hline \multirow{4}{*}{$\begin{array}{l}\text { 3. Form a system of indicators } \\
\text { for assessing the energy } \\
\text { efficiency of industrial } \\
\text { facilities }\end{array}$} & $\begin{array}{l}\text { Systematization of indicators } \\
\text { influencing the assessment of } \\
\text { energy efficiency. }\end{array}$ & $\begin{array}{l}\text { Systematization of the } \\
\text { principles for assessing the } \\
\text { energy efficiency of industrial } \\
\text { facilities. }\end{array}$ & $\begin{array}{l}\text { Substantiation of the } \\
\text { systematization of indicators } \\
\text { of energy efficiency of an } \\
\text { industrial facility. }\end{array}$ \\
\hline & $\begin{array}{l}\text { Systematization of approaches } \\
\text { to the formation of indicators } \\
\text { for assessing the energy } \\
\text { efficiency of facilities. }\end{array}$ & $\begin{array}{l}\text { Systematization of expert } \\
\text { opinions on the significance of } \\
\text { indicators in assessing the } \\
\text { energy efficiency of an } \\
\text { industrial facility. }\end{array}$ & $\begin{array}{l}\text { Systematized presentation of } \\
\text { energy efficiency indicators of } \\
\text { an industrial facility. }\end{array}$ \\
\hline & $\begin{array}{l}\text { Determination of the } \\
\text { principles for the formation of } \\
\text { indicators for assessing the } \\
\text { energy efficiency of industrial } \\
\text { facilities. }\end{array}$ & $\begin{array}{l}\text { Determination of significant } \\
\text { indicators for assessing the } \\
\text { energy efficiency of an } \\
\text { industrial facility. }\end{array}$ & $\begin{array}{l}\text { Allocation of groups of } \\
\text { indicators according to the } \\
\text { nature of consumption of } \\
\text { energy resources. }\end{array}$ \\
\hline & $\begin{array}{l}\text { Systematization of indicators } \\
\text { influencing the assessment of } \\
\text { energy efficiency. }\end{array}$ & $\begin{array}{l}\text { Systematization of the } \\
\text { principles for assessing the } \\
\text { energy efficiency of industrial } \\
\text { facilities. }\end{array}$ & $\begin{array}{l}\text { Substantiation of the } \\
\text { systematization of indicators } \\
\text { of energy efficiency of an } \\
\text { industrial facility. }\end{array}$ \\
\hline $\begin{array}{l}\text { 4. Provide a formalized } \\
\text { description of the process for } \\
\text { assessing the final indicator of } \\
\text { the energy efficiency of an } \\
\text { industrial facility }\end{array}$ & $\begin{array}{l}\text { Systematization of the applied } \\
\text { formulas for calculating the } \\
\text { energy efficiency indicators of } \\
\text { buildings and technological } \\
\text { processes or those proposed in } \\
\text { scientific research. } \\
\text { Definition of formulas for } \\
\text { calculating the energy } \\
\text { efficiency indicators of } \\
\text { buildings. }\end{array}$ & & $\begin{array}{l}\text { Representation of formulas for } \\
\text { calculating the integral } \\
\text { indicator of an industrial } \\
\text { facility. }\end{array}$ \\
\hline
\end{tabular}

The second stage is the organization of an expert survey and analysis of the results obtained, aimed at identifying the opinions of experts in the field of the efficiency of an industrial facility as an object for assessing energy efficiency and energy efficiency factors of industrial enterprises that are significant in developing an approach to assessing the energy efficiency of industrial facilities.

The third stage is the formation of a system of indicators for assessing the energy efficiency of an industrial facility, the results of the first two stages on the example of a new approach to assessing the energy efficiency of industrial facilities, based on the updated concept of the object of assessment, a new system of indicators for assessing energy efficiency and methods for determining indicators.

\section{Materials and Methods}

A study by the authors of the legislative and regulatory framework of various countries of the world, which is significant for assessing energy efficiency, showed that active work towards assessing the energy efficiency of facilities began already in the second half of the 20th century. In economically developed countries (USA, EU countries, Japan, Republic of Korea, etc.) and dynamically developing countries (China, Russia, etc.), by now, basic Laws (Directives) have been developed that define the national energy policy, regulate the consumption of energy by various objects and management of energy efficiency processes [7-17]. In most of these countries, to ensure energy efficiency, an integrated approach 
to energy conservation is being implemented in practice, while there are programs: in the USA - on the development of energy standards for buildings (Building Energy Codes Program, BECP) [18], on the justification of energy labeling of household appliances and electronic devices (Energy Star [19] and State Energy Program, SEP [20]), to support households in terms of insulation of buildings (Weatherization Assistance Program, WAP) [21]; in the countries of the European Union-on the labeling of energy-consuming equipment (Energy Star Program [19]) and the European Green Deal (action plan to turn Europe into a climate-neutral continent by 2050); in Japan-for equipping industrial facilities with energy-efficient technical means (Building Energy Management Systems Program), for equipping the residential sector with energy-efficient technical means and a smart home system (Home Energy Management Systems Program), for stimulating the development of household electrical appliances and office devices with very low energy consumption (Program "Creation of the best energy efficient products"), on product labeling and implementation of innovations without increasing their cost (Program "Top-Runner-Programs"), on the formation of energy-efficient information technology for the industrial sector and the development of new technologies (Project "Green IT Project") [22,23]. The variety of the considered programs speaks of great opportunities in improving energy efficiency in the modern world, and naturally determines the formulation of the question regarding the standards, which consolidate the already achieved results and principles that are universal in nature for certain objects in relation to which energy efficiency is considered. In the study, the authors examined objects related to industrial real estate and the processes carried out in it related to the consumption of energy.

To date, most countries have energy efficiency standards for residential and commercial buildings, which include design and regulatory indicators for assessing energy consumption and thermal protection of buildings, conducting energy audits and creating an energy management system [24-26]. For certification of buildings, taking into account energy consumption, as a rule, a point-rating system is adopted when assessing indicators (LEED, BREEAM, DGNB, WELL) [27-30]. In the European Union, the standard ISO 52000 of the EPB series (standards in the field of energy efficiency of buildings), which has been in force since 2017 and includes an assessment of energy consumption by a building and its life support systems, is the fundamental standard [31]. The most progressive design standards are considered to be highly efficient green buildings [32] and the international green construction code [33]. The analysis of the materials presented above showed that there is a high degree of elaboration of the issues of assessing the energy efficiency of buildings, including the definition of indicators for assessing energy consumption, their measurement and calculation, which became possible to systematize in this study.

The systematization of the assessment of the energy efficiency of real estate in European countries [34-38] showed that new and existing buildings are considered as the object of assessment: houses (residential and non-residential, multi-apartment and single-family, standard and individual, stone, brick, panel), public (administrative and commercial), industrial and others. Industrial buildings, as objects of energy efficiency assessment, are mentioned in the analytical materials of Italy. Similar objects of assessment are considered in the USA $[16,34,35]$. Considering the high degree of consumption of energy resources by industrial enterprises, significant energy losses during their operation due to the possible imperfection of building structures and their wear and tear, technological processes in the production of products $[39,40]$, the authors identified the relevance of developing a new approach to assessing the energy efficiency of enterprises in the industrial sector of the economy, and at the same time it was revealed the need to concretize the concept of "industrial facility".

The systematization of materials representing various approaches to the definition of an industrial facility has shown the following options for its identification:

- production facilities_-buildings used for production and assembly work, warehouse buildings [41]; 
- factory, plant-an industrial enterprise that includes one or more interconnected production, administrative and auxiliary buildings [42];

- industrial facility - a stationary technological unit, where one or more types of activities are carried out, stationary equipment and/or structures used in connection with any technological process for industrial production, an enterprise, its workshops, sections or sites for the production of products [43];

- industrial complex - real estate objects used for activities in the field of industry [44];

- production facility - enterprises of various industrial sectors [45];

- industrial enterprise - a complex of buildings and structures for the production of industrial products [45].

To solve the problem of determining the category of "industrial facility" for assessing energy efficiency, the method of analysis and classification of information was used, which made it possible to collect in a single system the available information on assessing the energy efficiency of objects for various purposes, to streamline a significant information resource, to identify the problems of determining the category of "industrial facility". The use of the method of expert assessments determined the significant features of the enterprise in the industrial sector of the economy, which require consideration when assessing their energy efficiency. The application of these methods provided an understanding of the need to concretize the definition of an industrial facility for the purpose of assessing its energy efficiency, which makes it possible to switch to a systematic representation of the assessment of the energy efficiency of industrial facilities, which is invariant to industry affiliation.

The study of the materials collected by the authors showed the need for their analysis in accordance with the tasks set. It is important to note that the interpretation of the concept of an "industrial facility" in the studied sources is generally similar in content, and the specificity of its formulation is due to the difference in tasks solved in the development of documents (programs and standards). In this regard, it became necessary to obtain a qualitatively different material in the study-actual views of leading experts in this field from a number of countries, whom the authors attracted to form a consolidated position on clarifying the concept that is essential for solving the issues of assessing the energy efficiency of enterprises in the industrial sector of the economy - "industrial facility" and related to its specific principles of conducting the assessment. The sample of Russian and foreign experts was formed on the basis of the developed criteria for assessing the competencies of experts corresponding to the objectives of the study.

A questionnaire consisting of two blocks was used as a survey tool. The first block included general questions to collect data on experts, characterizing their professional interests and experience in the field under study. In this block, brief information about the expert was recorded: the name and surname of the expert, their position, E-mail, the country they represent, the region, the name and type of activity of the company in which they work, as well as interest in receiving information about the results of the survey. The questions in this block were mostly open-ended. The second block directly contained questions on the research topic. All the questions in this block were mandatory, which made it possible to get answers from the respondents to all the questions posed in it. Due to the fact that in modern conditions, an online survey is one of the most convenient methods for conducting a survey, the questionnaire was compiled in the simplest application for administering surveys-Google Forms.

As a way of agreeing on the expert opinions, the "majority rule" was used, according to which the interpretation was chosen, which was adhered to by the majority of experts. At the final stage of the study, a report was generated containing a description of the survey results and recommendations for their further application were given. The experts unanimously confirmed the expediency of separating the assessment of the energy efficiency of enterprises in the industrial sector of the economy into an independent research area and the need to clarify the definition of the concept of an "industrial facility". At the same time, they noted the complexity of the object of assessment, which entails considering it as an integral complex, described by a system of energy efficiency indicators, requiring 
quantitative measurement and formalization of the assessment process. On the basis of the materials obtained, the first of the tasks of the study was solved-the author's definition of the concept of an "industrial facility" as an industrial building (structure) or a complex of adjacent buildings (structures) was proposed, including its entire property complex, which has a single engineering infrastructure that ensures production activities as a business entity.

The transition to the next research task, related to the indicators for assessing the energy efficiency of objects, determined the need to obtain materials regarding the modern practice of its assessment in different countries of the world to determine the essential aspects of the assessment and the results achieved. The solution to the problem of identifying the conditions for assessing the energy efficiency of an industrial facility is based on the use of comparative analysis and the method of expert assessments. The use of these methods made it possible to identify the most disputable areas of research and determine the authors' position on the systemic representation of the object of assessment and the principles of forming a system of indicators when developing a new approach to assessing the energy efficiency of industrial facilities, to make a decision on the choice of factors affecting energy efficiency indicators, to determine the composition of assessment indicators and to determine their significance, which ensured the representativeness of the results.

In general terms, the level of energy efficiency of the object of assessment is determined based on the characteristics of consumption or the consumption of energy resources. Comparative characteristics of materials related to the consumption of energy resources in different countries showed certain differences. These include the following: of total building energy consumption, $89 \%$ of the countries in the sample surveyed include heating, $84 \%$ of countries include hot water, 79\% of countries include cooling, 74\% include lighting, and minimum countries account for auxiliary equipment; $21 \%$, household electrical appliances; $16 \%$ and air humidification; 11\% (Figure 1). It can be concluded that these directions of consumption of energy resources should be reflected in the system of indicators for assessing the energy efficiency of an industrial facility [35].

According to the Comparative Review of Energy Efficiency Standards and Technologies in Buildings in the UNECE Region, the most significant conditions related to energy efficiency in buildings are: availability of heating and hot water supply (40 of the analyzed countries); thermal characteristics and geometry of the building (enclosing structures, floors, etc.) (38 countries); air conditioning (37 countries); forced (mechanical) and natural ventilation (37 countries); location and orientation of buildings (36 countries); passive solar systems and solar protection (36 countries). Conditions such as passive cooling (8 countries), heat recovery (7 countries) and dehumidification (2 countries) [35] (Figure 2) are considered limitedly.

The investigated materials showed a difference in approaches to assessing energy efficiency even at the stage of determining the conditions that affect it. In particular, in the United States, the following are considered as conditions for the energy efficiency of buildings: climatic parameters at the site of an object, parameters of the internal microclimate, dimensions of a building, heat-shielding properties of a building, parameters of engineering systems and the number of people (living in a building) [35]. In the Russian Federation, when assessing energy efficiency, conditions are considered related to architectural and engineering solutions, the characteristics of individual structural elements of a building that are included in projects during construction, overhaul or reconstruction and on the basis of which the specific indicators of energy resource consumption are estimated [14]. 


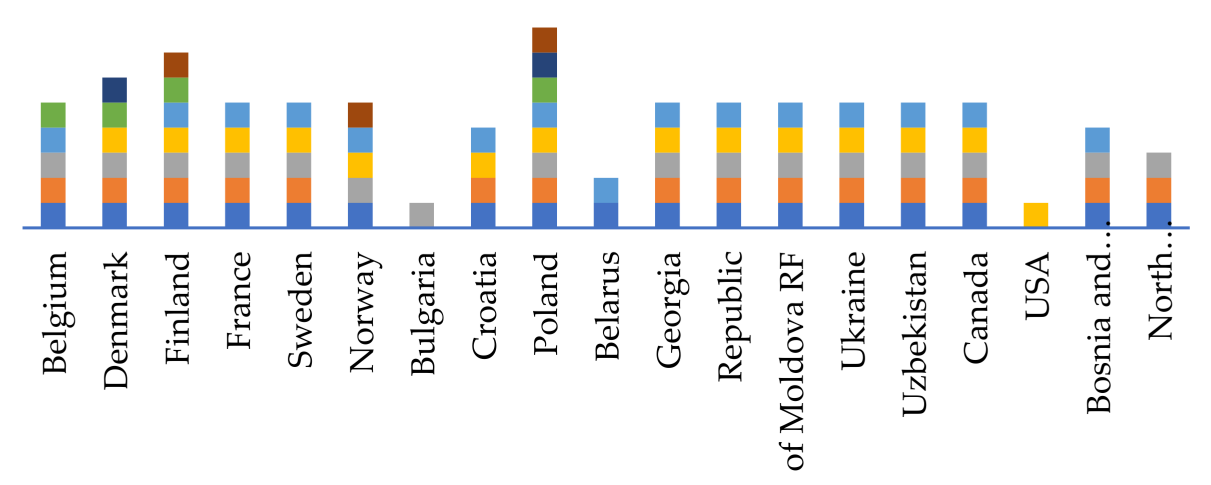

- Consumption of energy resources for household electrical appliances

Consumption of energy resources for humidification

Consumption of energy resources for auxiliary equipment

Consumption of energy resources for ventilation

Consumption of energy resources for heating lighting

Consumption of energy resources for hot water

Consumption of energy resources for cooling

Consumption of energy resources for heating

Figure 1. Accounting for the consumption of energy resources in terms of energy efficiency of buildings (built by the authors based on the "Comparative review of existing technologies to improve the energy efficiency of buildings in the UNECE region in 2019" [35]).

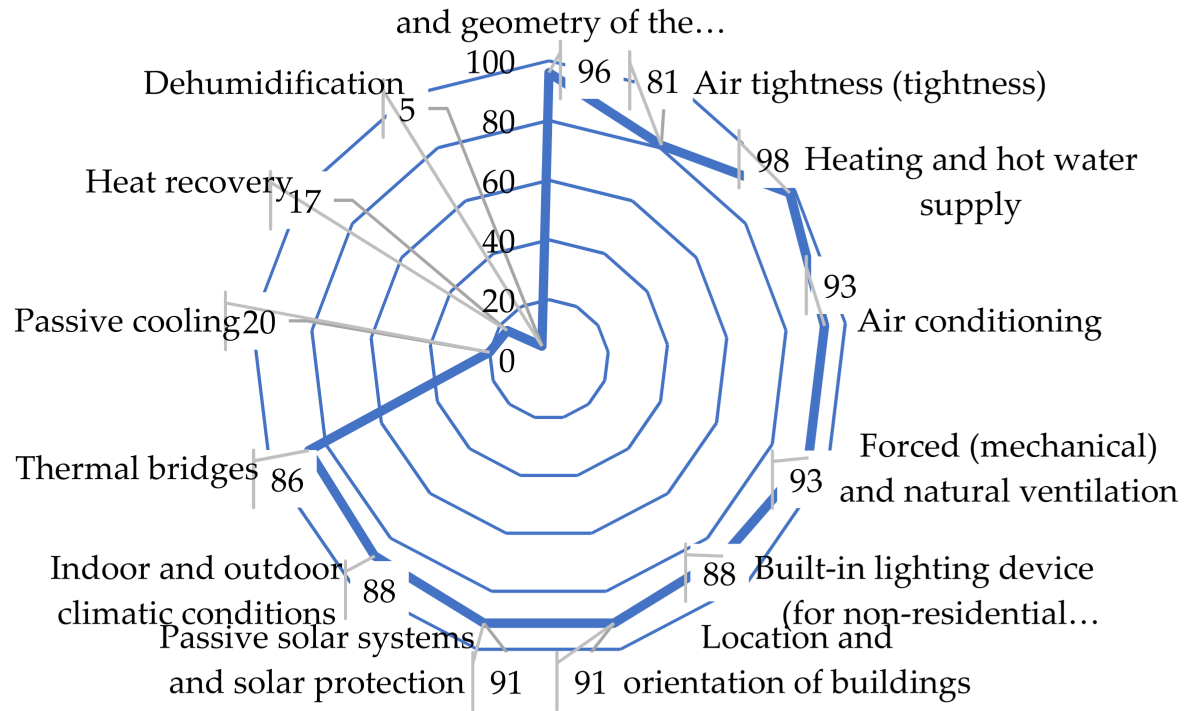

Figure 2. Consideration of energy efficiency conditions when assessing the energy efficiency of buildings (constructed by the authors based on the "Comparative Review of Energy Efficiency Standards and Technologies for Buildings in the UNECE Region for 2018" [35]).

In this regard, the authors summarized the opinions of experts obtained as a result of an expert survey conducted by them, aimed, among other things, at identifying the conditions for ensuring energy efficiency in determining the energy efficiency of an industrial facility (Figure 3). 


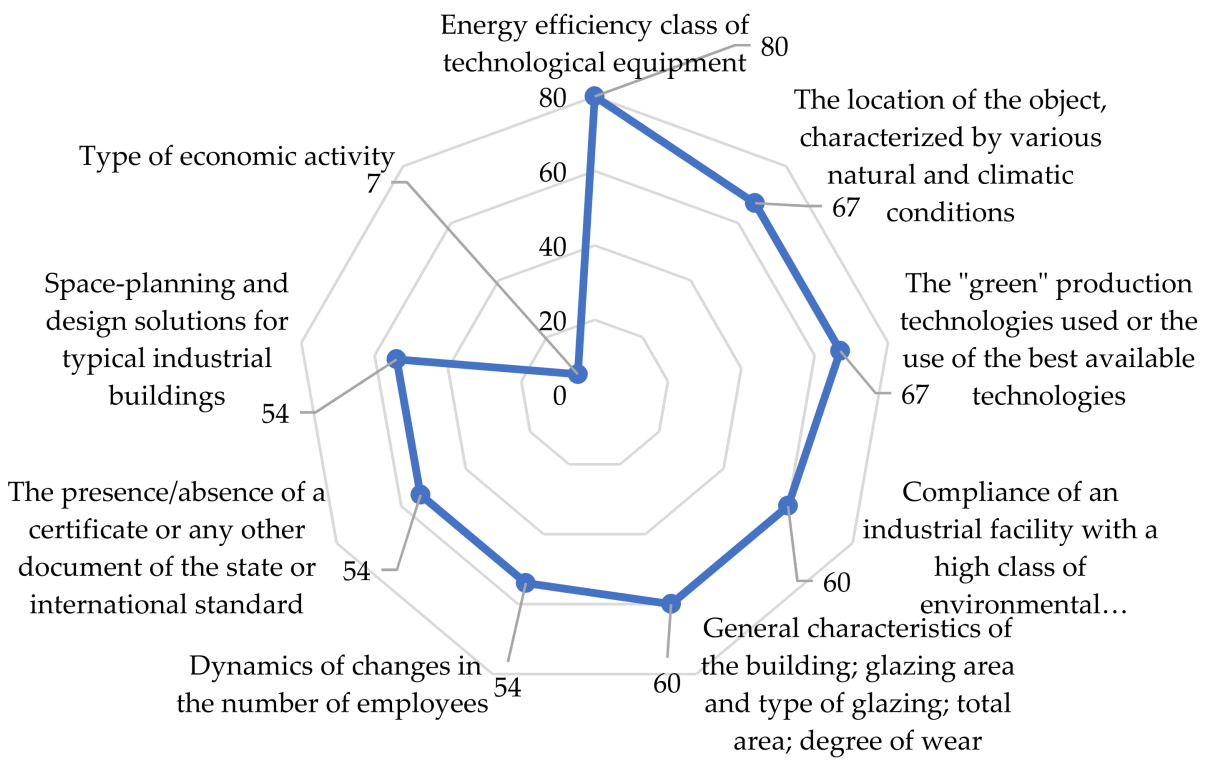

Figure 3. Distribution of expert opinions on the importance of conditions for ensuring energy efficiency of an industrial facility, $\%$ of respondents.

According to experts, the most significant conditions include: the location of the assessment object to take into account the natural and climatic features of the territory $(67 \%$ of experts); general characteristics of the building (year of construction, number of stories), glazing area and type of glazing, area, degree of wear (60\% of experts); space-planning and design solutions for typical industrial buildings ( $54 \%$ of experts). Taking into account the specifics of an industrial facility as an object for the production of industrial products, the experts noted the need to take into account the energy efficiency class of technological equipment ( $80 \%$ of experts) and the used "green" production technologies or the use of the best available technologies (67\% of experts). Focusing on modern environmental trends, they recommended taking into account the compliance of an industrial facility with an environmental class, confirmed by the presence of a "green" certificate in one or several international systems LEED, BREEAM, DGNB and others (60\% of experts) and the presence/absence of a certificate or any other document state or international standard, certifying the existence of an energy policy, strategy or energy management system at the enterprise of the industrial sector of the economy that meets the requirements of ISO 50001 ( $54 \%$ of experts). This emphasizes the importance of accounting in determining the energy efficiency of industrial facilities of technological processes for the production of industrial products, as well as energy efficiency and environmental friendliness management.

The transition in the study to the development of principles and indicators for assessing the energy efficiency of industrial facilities required the use of traditional methods of scientific knowledge related to the studied subject area. In the course of work, at certain stages, the authors widely used research methods included in the group of analytical methods, the system method and mathematical methods (analysis and synthesis, scaling and classification, comparative analysis, induction and deduction, statistical methods, the method of expert assessments, the establishment of quantitative relationships between the studied phenomena, etc.), which made it possible to provide an integrated solution regarding the proposed system of indicators for assessing the energy efficiency of industrial facilities. In particular, based on the methods of analysis and synthesis of previously used approaches to assessing energy efficiency, a new approach has been formed to ensure a meaningful relationship between the definition of an industrial facility and the proposed system of energy efficiency indicators within the selected context. The use of methods for analyzing and classifying information made it possible to collect, in a single system, the available information for assessing the energy efficiency of objects for various purposes, to streamline a significant information resource and to determine the conceptual apparatus for 
the formation of each of the proposed indicators. This provided not only the specification of the definition of an industrial facility for the purpose of assessing its energy efficiency, presented in the article above but also the development on this basis of an integrated approach to assessment, taking into account the indicators already used in practice for assessing the energy efficiency of non-industrial facilities (residential, public facilities) when creating a new approach for assessing the energy efficiency of industrial facilities.

Comparative analysis was used to analyze the correspondence of energy consumption indicators and their indicative values (set, for example, at the state level), as well as to formulate proposals for discussion on the ranking of the values of energy efficiency indicators of industrial facilities. The systematic method used in the research made it possible to form a general vision of the problem and, in relation to the object of research, to carry out a comprehensive analysis of the current conditions of energy consumption by an industrial facility both during the operation of buildings and in the production of finished products, which are also considered from the standpoint of organizing the management of these processes. In addition, the system method made it possible to take into account the hierarchy of the representation of the object under study, which makes it possible to determine the priority of the processes of energy consumption by an industrial object relative to the control processes. This made it possible to present an assessment of the energy efficiency of an industrial facility in the form of decomposition of interrelated groups of indicators and to structure in the study the processes of energy consumption by an industrial facility. The proposed structuring is presented in the form of three subsystems of indicators characterizing the energy efficiency of the building, the energy efficiency of technological processes and the provision of energy efficiency combined with environmental friendliness in terms of organizing effective management on the principles of ESG. The use of the method of comparative analysis in combination with the systemic method provided the basis for the formation of a new system of indicators for assessing the energy efficiency of industrial facilities, as well as providing formulas for calculating indicators for assessing the energy efficiency of an industrial facility.

The use of the method of expert assessments, which was modified by the authors in relation to the studied subject area, made it possible to concretize the conditions for assessing an industrial facility and give it meaningful characteristics, make a decision on the choice of factors affecting the level of energy efficiency indicators, determine the system of assessment indicators and rank them according to their degree of significance, which ensured the representativeness of the results. When using the method of expert assessments, in addition to questionnaires, interviews were conducted with leading experts, which made it possible to identify the most controversial areas of research and make a reasonable choice of methods that best suit the tasks being solved. The logic of determining the energy efficiency indicators of industrial facilities is described using the mathematical apparatus of formalizing the consumption of energy resources and modeling individual processes for managing energy efficiency and environmental friendliness of an industrial facility, taking into account the principle of multiple options for the types of resources, estimated and standard values of the level of their consumption, which allows a flexible approach to the formation of a system of energy efficiency indicators.

\section{Results}

In the process of researching the collected material using the considered methods, the author's position was formed regarding the system of energy efficiency indicators of an industrial facility and to solve the assigned tasks.

To solve the problem of determining factors for assessing the energy efficiency of an industrial facility, the consolidated information of the analysis of the regulatory and legal framework in the field of energy efficiency and the results of a comparative analysis of the conditions for ensuring energy efficiency of industrial enterprises, presented in the practice of various countries of the world, was used. Comparative characteristics showed a wide variety of approaches to energy efficiency management in buildings and production processes. 
The identified conditions for energy efficiency, taking into account the current focus on compliance with the principles of sustainable development and ESG, were supplemented by new conditions in the management of energy efficiency and environmental friendliness of an industrial enterprise that operates on the basis of the industrial facility being assessed. The question of assessing the significance of energy efficiency conditions in the industry was included in an expert survey conducted by the authors, on the basis of which the factor space for ensuring the energy efficiency of an industrial facility was determined.

The classification of factors for assessing the energy efficiency of an industrial facility is based on signs that reflect conditions essential for ensuring the energy efficiency of an industrial facility. The classification of factors for assessing the energy efficiency of an industrial facility proposed by the authors includes general and specific factors. A sign of distinguishing into the group of general factors for assessing the energy efficiency of an industrial facility is the use of traditional resources necessary for the maintenance of buildings and the implementation of the technological process. This group includes the factors of energy consumption and the need for them. Energy consumption factors are controllable, focus on compliance with standards and take into account technical characteristics of the building and equipment, energy consumption depending on their type (fuel, heat energy, electricity), water consumption for building maintenance and production activities, features of technological processes, specifics activities of industrial facilities, etc. Factors of demand for energy resources are determined by the environment in which the efficient use of energy resources is carried out.

An indication of the selection of specific factors for assessing the energy efficiency of an industrial facility into the group is the use of special resources that are applicable for the maintenance of buildings and the implementation of technological processes. This group includes the factors of using non-traditional and interchangeable types of energy resources, the availability of automation of building engineering systems and technological processes, the environmental characteristics of the building and technological processes. The group of specific factors of energy efficiency of an industrial facility includes the factors of energy efficiency and environmental friendliness, which are determined by the efficiency and timing of those carried out by the enterprise, which operates on the basis of the industrial facility being assessed, investments in energy-saving measures, the presence of a certified energy management system at the enterprise in accordance with the requirements of the international standard ISO 50001 and the monitoring of energy consumption, using technologies from the list of the best available technologies (BAT) in the production process.

The features of the object of assessment and a significant number of specific factors of influence on the characteristics of the consumption of energy resources during the functioning of industrial production during the operation of the building and the creation of products, the importance of which is constantly increasing in modern conditions, determined the need to form a new system of indicators for assessing the energy efficiency of an industrial facility. It was based on the following principles for solving this problem:

- consistency, representing the integrity and interconnectedness of the elements of an industrial facility (buildings, structures, machines, equipment and technological processes) and their consumption of all types of energy resources;

- complexity, taking into account all aspects of energy consumption of an industrial facility, types and quantities of consumed types of energy resources in accordance with technological processes, as well as regulatory and technical documentation, standards and other regulations;

- the sequence that determines the processes for assessing the energy efficiency of industrial facilities and the regulation of the consumption of energy resources by an industrial facility in the context of focusing on the principles of ESG and sustainable development;

- comparability, providing a unified format for presenting energy efficiency indicators of an industrial facility and uniformity of measurements of indicators of consumption of energy resources; 
- rationality, which determines the assessment of the energy efficiency of an industrial facility on the basis of determining the necessary and sufficient level of consumption of energy resources for products at an industrial facility of the required quality and quantity;

- functional interconnection, ensuring the need to assess energy efficiency, taking into account the requirements of resource consumption and resource-saving in technological processes of an industrial facility, energy consumption and energy-saving standards, control of energy resources consumption;

- the continuity of processes, which implies the possibility of ensuring the continuity of the processes of strategic, tactical and operational planning of energy-saving and energy-efficiency indicators of industrial facilities, as well as their monitoring at all stages of the life cycle of an industrial facility;

- orientation towards the market situation, which implies the correlation of the assessed indicators of energy saving and energy efficiency in conjunction with the position of an industrial enterprise in specialized markets;

- the unity of the approach, providing an identical presentation of the logic of formation, definition, accounting, analysis, adjustment of indicators of consumption of energy resources, as well as the indicator of energy efficiency of the evaluated industrial facility;

- the obligation to take into account the requirements of the current legislation of the countries and the mandatory standards for the consumption of all types of energy and fuel consumption in the production process;

- environmental friendliness, which determines the need to provide an opportunity to characterize the impact of the results of the activity of an industrial enterprise on the components of the environment when determining the indicators of energy saving and energy efficiency of industrial facilities.

The systematization of the proposed indicators for assessing the energy efficiency of industrial facilities was carried out from the point of view of participation in the final result of the consumption of energy resources. The first group of indicators is associated with the building as a place where the production process is carried out, the second, directly with the technological process of manufacturing products, and the third, with the management process aimed at ensuring energy efficiency and environmental friendliness of the building and the technological process.

The new system of indicators for assessing the energy efficiency of an industrial facility within the framework of the three identified groups takes into account the indicators recommended by experts for use in assessing the energy efficiency of industrial facilities and analyzed by the authors taking into account the above principles (Figure 4).

In the new system of indicators for assessing the energy efficiency of an industrial facility, the authors used the values and characteristics of the conditions for their formation to systematize indicators, which have a decisive influence on the estimated energy efficiency of an industrial facility. Let us briefly characterize the substantive characteristics of the main ones that play a system-forming role. The investigated and selected indicators, first of all, include such indicators as: total power of electrical receiving devices; energy intensity of production per unit of production (consumption of all energy resources referred to the total volume of production in monetary terms); total consumption of energy resources; coefficients of performance (COP) and fuel use (FU) of production equipment used for the main production and auxiliary processes; the share of payments for energy resources in the value of manufactured products; main product range. 


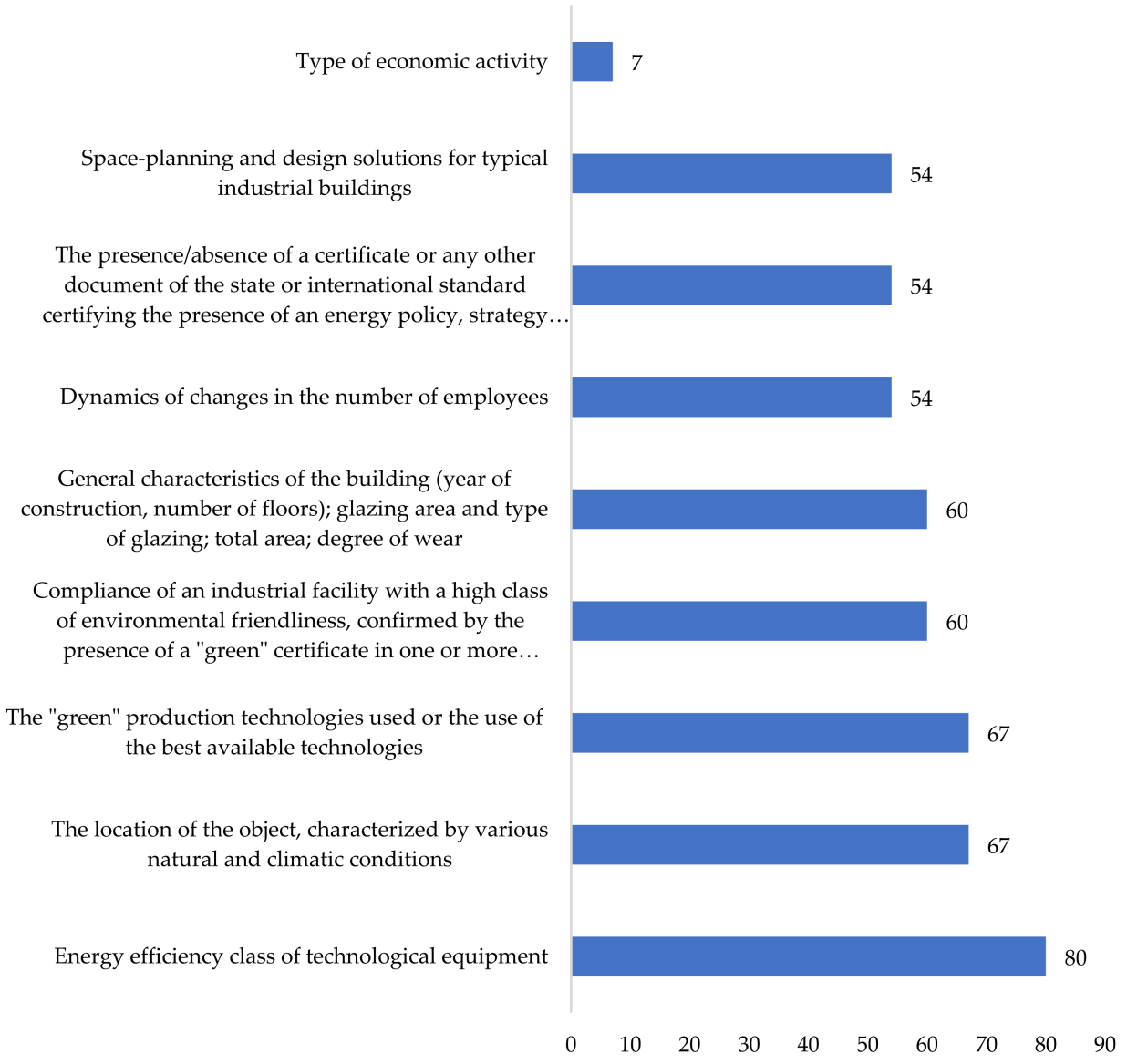

Figure 4. Distribution of expert opinion on the significance of indicators for assessing the energy efficiency of industrial facilities.

The natural indicator of the total power of electrical receiving devices is important, which characterizes the amount of energy consumption depending on the type of electrical equipment and a specific consumer, seasonal load, characteristics of technological processes, installed capacity and efficiency, etc. The natural indicators also include the consumption of energy resources. It reflects the total amount of energy resources consumed by an industrial facility in a comparable form for a certain period of time. Taking these indicators into account in the system of energy efficiency indicators of an industrial facility will make it possible to determine not only the amount of energy resources required for the operation of power equipment and an industrial facility as a whole in the time period but also to ensure control over the processes of their consumption. The specific indicator of the energy intensity per unit of production characterizes the energy efficiency of the production process in terms of the amount of all energy resources in value terms per unit of the value of the production of an industrial enterprise. Relative indicators of efficiency and FU characterize the amount of useful energy resources and fuel to their total amount. In the system of energy efficiency indicators of an industrial facility, their place is ensured not only by a direct influence on the general level of energy efficiency of an industrial facility but also by the information content of its dynamics when organizing energy efficiency management of an industrial facility. The share of payments for energy resources in the value of manufactured products characterizes the energy efficiency of the technological process and, as an integral part, determines the level of energy efficiency of an industrial facility as a whole and how a controlled value ensures its dynamics.

The system of indicators for assessing the energy efficiency of an industrial facility formed by the authors is presented in Table 2 . 
Table 2. The system of indicators for assessing the energy efficiency of an industry.

Source of Expense Energy Type Monitoring Indicator

First group of indicators-Energy efficiency of buildings

1.1. Resource efficiency in buildings

\begin{tabular}{|c|c|c|}
\hline \multirow{7}{*}{ Energy consumption } & \multirow{2}{*}{ Fuel (boiler-furnace, motor) } & $\begin{array}{l}\text { Fuel consumption for heating and ventilation of the building, hot } \\
\text { water supply }\end{array}$ \\
\hline & & Fuel consumption system status \\
\hline & \multirow{3}{*}{ Thermal energy } & $\begin{array}{l}\text { Heat consumption for heating and ventilation of the building, hot } \\
\text { water supply }\end{array}$ \\
\hline & & Condition of external structures of the building \\
\hline & & Heat consumption system status \\
\hline & \multirow[t]{2}{*}{ Electricity } & $\begin{array}{l}\text { Electricity consumption for lighting, utility systems and air } \\
\text { conditioning systems }\end{array}$ \\
\hline & & Power system status \\
\hline \multirow{2}{*}{ Water consumption } & & Water consumption for engineering systems \\
\hline & & Condition of the water supply system of the building \\
\hline
\end{tabular}

\subsection{Consumption of non-traditional and other types of energy resources in buildings}

\begin{tabular}{ll}
\hline & Renewable energy consumption \\
\hline & Secondary energy consumption \\
\hline
\end{tabular}

\subsection{Automation of building engineering systems}

The presence of a centralized dispatching system with the possibility of individual (zonal) regulation

Availability of local automation systems for engineering support systems

\subsection{Environmental characteristics of the building}

Environmental friendliness of building materials and structures

Sustainability of the building

Environmental characteristics of the air environment (microclimate)

Second group of indicators-Energy efficiency of technological processes

2.1. Efficiency of resource consumption in production

\begin{tabular}{lll}
\hline \multirow{2}{*}{ Energy consumption } & Fuel (boiler-furnace, motor) & Fuel consumption for production \\
\cline { 3 - 3 } & Technical condition of equipment \\
\hline \multirow{2}{*}{ Thermal energy } & Heat consumption for production \\
\cline { 2 - 2 } & Electricity & Technical condition of equipment \\
\cline { 2 - 2 } & Technical condition of equipment \\
\hline
\end{tabular}

2.2. Consumption of non-traditional and other types of energy resources in the production process

Renewable energy consumption

Secondary energy consumption

2.3. Automation of technological processes

Availability of modern automation systems for technological processes 
Table 2. Cont.

Source of Expense $\quad$ Energy Type Monitoring Indicator

2.4. Environmental characteristics of technological processes

Environmental performance of equipment

Sustainability of raw materials used in the production process

2.5. Energy efficiency of production

Energy intensity of production, thousand tons/thousand rubles.

The share of payments for energy resources in the value of manufactured products (works, services)

Efficiency of technological equipment

The level of electricity losses in the electrical networks of the industrial complex

The level of heat losses in heating networks

Application of energy-saving equipment

Renewable energy consumption

Secondary energy consumption

2.6. Automation of technological processes

Availability of modern automation systems for technological processes

2.7. Environmental characteristics of technological processes

Environmental performance of equipment

Sustainability of raw materials used in the production process

2.8. Energy efficiency of production

Energy intensity of production, thousand tons/thousand rubles.

The share of payments for energy resources in the value of manufactured products (works, services)

Efficiency of technological equipment

The level of electricity losses in the electrical networks of the industrial complex

The level of heat losses in heating networks

Application of energy-saving equipment

Third group of indicators-Ensuring energy efficiency and environmental friendliness of an industrial facility

3.1. Energy efficiency management of an industrial facility

Efficiency of investments in energy-saving measures

Energy management system ISO 50001

Energy monitoring

Use of technologies from the list of the best available technologies (BAT)

Payback of energy-saving measures

3.2. Environmental management of an industrial facility

The quality of sanitary protection

Environmental management system ISO 14000

The quality of waste collection and disposal 
The proposed system of indicators for assessing the energy efficiency of an industrial facility includes quantitative and qualitative indicators. It is assumed that quantitative indicators are determined by calculation, and qualitative ones are based on expert opinion. To ensure the comparability of all indicators in the system, quantitative and qualitative indicators should be converted into a single measurement system, for example, into points.

The first group of indicators, "Energy efficiency of the building", includes four subgroups. The subgroup of indicators of resource consumption in a building provides information on the consumption of all types of fuel (boiler, stove, motor), heat energy, electricity and water consumption used to ensure the functioning of the building. These quantitative indicators are supplemented by qualitative indicators reflecting the condition of the building, its structural elements and systems and the possibility of changing the indicators of energy consumption and the structural elements and systems themselves to improve the energy efficiency of an industrial facility. The allocation of quantitative indicators for the consumption of non-traditional and other types of energy resources in buildings into an independent subgroup is due to the focus on ensuring the requirements for environmental friendliness of the building and reducing costs when implementing measures to improve the energy efficiency of an industrial facility. In the subgroup "automation of building engineering systems", qualitative indicators are presented that reflect the presence or absence of dispatching systems and automation of the process of energy consumption during building operation, as well as the ability to manage their implementation in the building operation process when solving the issue of improving the energy efficiency of an industrial facility. The subgroup of quality indicators reflecting the environmental characteristics of the building itself and used in the construction of environmental materials, including taking into account the characteristics of the air environment, is directly related to modern trends in ensuring ESG principles.

The second group of indicators, "Energy efficiency of technological processes", includes five subgroups. The first four subgroups of indicators coincide in content with similar subgroups in the group of indicators "Energy efficiency of the building", but the quantitative and qualitative indicators presented in them are related to the technological processes of production at an industrial facility. At the same time, the indicators of consumption of energy resources and water are supplemented with qualitative indicators of the state of equipment (for example, the degree of wear, innovation), which makes it possible to manage indicators of the consumption of energy resources and water through the management of quality characteristics in order to increase the energy efficiency of an industrial facility. Additionally, this subgroup includes quantitative and qualitative indicators of energy efficiency of production to determine the degree of compliance of the technological process of production with environmental friendliness and ESG principles and obtain information for making management decisions to improve the energy efficiency of an industrial facility in this context.

The third group of indicators, "Ensuring energy efficiency and environmental friendliness of an industrial facility", includes two subgroups of quantitative and qualitative indicators related to the management of energy efficiency of an industrial facility (efficiency of investments in energy-saving measures, the presence of an ISO 50001 energy management system, monitoring of energy consumption, the use of BAT technologies and the return on investment of energy-saving measures) and management of the environmental friendliness of an industrial facility (the quality of sanitary protection, the presence of an ISO 14000 environmental management system and the quality of waste collection and disposal), in accordance with the principles of environmental friendliness and ESG, guaranteeing a focus on improving the energy efficiency of an industrial facility and ensuring its development in line with modern energy-saving trends.

For the values of qualitative and quantitative indicators of energy efficiency of an industrial facility, the task of developing formulas for calculating them using a point assessment was solved. 
The energy efficiency of a building in terms of the consumption of energy and nontraditional resources in points is determined by the formula:

$$
S b l d \_l=\sum_{i=1}^{m} S_{b l d},
$$

where Sbld_l is the sum of points assigned to the building in accordance with the consumption of all energy and non-traditional resources, and $S b l d_{i}$ is the number of points assigned to the building in accordance with the consumption of an energy or non-traditional resource of the $\mathrm{i}$-th type $(i=1, \ldots m)$.

The level of consumption of energy and non-traditional resources of the i-th type in points is determined by the formula:

$$
\operatorname{Sbld}_{i}=\sum_{j=1}^{n} d i_{j},
$$

where $S_{b l d_{i}}$ is the sum of points assigned to the building in accordance with the consumption of the energy and non-traditional resource of the $i$-th type for each $j$-th direction of expenditure $(j=1, \ldots, n)$ and $d i_{j}$ is the number of points assigned to the building in accordance with the percentage of deviation of the actual values of the consumption of the energy and non-traditional resource of the $i$-th type in the $j$-th direction of expenditure.

When calculating the percentage of deviation in points, the following designations are used: aij is the actual value of the energy and non-traditional resource of the i-th type, spent on the building in the $\mathrm{j}$ direction, $\mathrm{Nij}$ is the normative value of the energy and non-traditional resource of the $i$-th type, spent on the building in the $j$ direction and $P i j$ is the percentage value of the indicator of the actual consumption of the energy and non-traditional resource of the i-th type in the j-th direction of consumption, referred to the building, in comparison with the standard indicator.

To calculate the indicator, the formula is used:

$$
\begin{aligned}
& S P i j=a i j \times N i j, \\
& d i j=P i j-100 \% .
\end{aligned}
$$

The number of points for a specific percentage of deviation is assigned based on an expert survey.

When assessing the qualitative indicators of the energy efficiency of an industrial facility, the points are assigned based on expert analysis. In this case, the assessment of the quality characteristics of the energy efficiency of the building is determined by the formula:

$$
S b l d \_q=\sum_{z=1}^{Z} S b l d \_q_{z},
$$

where Sbld_q is the sum of points, taking into account the quality characteristics of the energy efficiency of the building, and Sbld $q_{z}$ is the sum of points that determines the qualitative characteristics of the energy efficiency of the building based on the opinion of experts on the criterion $z(z=1, \ldots, Z)$.

The energy efficiency of buildings in points is determined by the formula:

$$
\text { Sbld }=\text { Sbld_l }+ \text { Sbld_q },
$$

where Sbld is the sum of points assigned to the building in accordance with the consumption of all energy and non-traditional resources, and points for the quality characteristics of the building, and Sbld_l is the sum of points assigned to the building in accordance with the consumption of all energy and non-traditional resources.

The calculations of the energy efficiency indicator for technological processes are carried out in the same way as the calculation of the energy efficiency indicators of a building. 
To determine the qualitative characteristics of the energy efficiency of technological processes, the following formula is used:

$$
S t p_{-} q=\sum_{z=1}^{Z} S t p_{-} q_{z}
$$

where Stp_q is the sum of points, taking into account the qualitative characteristics of the energy efficiency of technological processes, and $S t p_{-} q_{z}$ is the number of points assigned to the quality of energy efficiency of technological processes by the opinion of experts to the criterion $z(z=1, \ldots, Z)$.

The energy efficiency of technological processes in points is determined by the formula:

$$
\text { Stp }=S t p_{-} l+S_{t} p_{-} q,
$$

where Stp is the sum of points assigned to technological processes in accordance with the consumption of all energy and non-traditional resources, and points for the quality characteristics of the building, and Stp_l, is the sum of points attributed to technological processes in accordance with the consumption of all energy and non-traditional resources.

The quality characteristics of ensuring energy efficiency and environmental friendliness are determined by the formula:

$$
\operatorname{Sem}=\sum_{z=1}^{Z} \operatorname{Sem} \_q_{z}
$$

where Sem is the sum of points, taking into account the qualitative characteristics of environmental and energy management at the enterprise, and $S_{e m} q_{z}$ is the number of points assigned to the quality of environmental and energy management according to experts, with the criterion $z(z=1, \ldots, Z)$.

The final indicator of the energy efficiency of an industrial facility in points:

$$
\text { Seff }=\text { Sbld }+ \text { Stp }+ \text { Sem }
$$

The final value of the energy efficiency indicator of an industrial facility is the basis for classifying an industrial facility as a certain energy efficiency class.

\section{Discussion}

In the course of the analysis of open data and the results of an expert survey, the absence in the world practice of national and international systems for assessing the energy efficiency of industrial facilities was revealed. This fact allows us to assume that the system of indicators for assessing the energy efficiency of industrial facilities proposed by the authors can not only be integrated into the national rating systems but also become the basis for international rating systems for assessing the energy efficiency of industrial facilities. This proposal reflects the possibility and necessity of using the results obtained at different levels of energy efficiency management, at the level of micro, meso and macroeconomic systems, which correspond to the organization of energy efficiency management of industrial facilities at the level of an individual enterprise, region, state as a whole and internationally. At the same time, it is the scale of the possible use of the system for assessing the level of energy efficiency of industrial facilities that determines the need for discussions in solving the problem of ensuring the uniformity of measurements.

Considering the issue of the uniformity of energy efficiency measurements, it should be noted that the expert opinion of the survey participants, combined with the analysis of the researchers' materials, allowed the authors to take into account the most significant factors in ensuring energy efficiency and proposing the corresponding estimated indicators, which are presented above. At the same time, it is provided that the energy efficiency of a building and technological processes is assessed based on the results of an energy 
survey of an industrial facility, but the assessment of quantitative values, for example, at the levels of "high energy efficiency" and "low energy efficiency" are completely uncertain. The assessment situation is further complicated by the fact that there are no standards for the level of specific energy consumption (energy intensity) of production for all types of industrial activity in the considered reference group of countries. There are standards for building structures (for example, restrictions on heat loss) and, in part, for equipment for some types of industrial production. At the same time, in the new approach to assessing the energy efficiency of industrial facilities proposed by the authors, the issues of ensuring energy efficiency and environmental friendliness are predetermined for the first two groups of indicators, to a greater extent reflecting the realization of the energy-saving potential at an enterprise that operates on the basis of the industrial facility being assessed.

When analyzing acceptable assessment methods, two options were considered, used in combination with each other: an assessment based on the calculation of the specific indicator of energy consumption and its comparison with standard (reference) indicators; a rating score based on the scoring model. In this regard, such a combination of them was used, which excludes contradictions while ensuring the uniformity of energy efficiency measurements, and allows an unambiguous interpretation of the obtained quantitative values according to the proposed formulas. However, as the studies have shown, the use of scoring and the implementation of rating of industrial facilities on this basis, due to the differences in the organization of this activity in different countries of the world, requires the correct choice of the main positions for rating, which are proposed for discussion in this section.

Let us take a look at the context of this discussion. Recently, rating systems for evaluating various objects have become most widespread. This fact is connected not so much with the simplicity of the assessment procedures but with the possibility of providing greater coverage of the factors taken into account in the assessment, the convenience of comparing the results obtained for the assessment objects by a set of heterogeneous indicators, as well as the visibility of the presented results in dynamics, taking into account the assurance of the uniformity of measurements. Moreover, important advantages of the rating assessment are the possibility of comparisons in the presence of not only quantitatively measurable but also qualitatively assessed parameters/characteristics of the object. For example, in the proposed approach to assessing the energy efficiency of industrial facilities, due to the integration of two assessment methods in determining indicators, it became possible to take into account indicators that were previously rarely used, for example, the use of RES and BAT.

It is possible to take into account the presence of the enterprise, which operates on the basis of the assessed industrial facility, a policy of sustainable energy-efficient and environmental development, confirmed by the corresponding certificates ISO-50001 and ISO-14001, as part of the third group of indicators proposed by the authors for assessing the processes of ensuring energy efficiency and environmental friendliness. This opportunity is of particular importance in modern conditions due to the trend of transition of the economies of many countries to low-carbon energy on a global scale and the policy measures introduced in a number of countries in this direction, including mandatory "carbon reporting". Therefore, the proposed system includes a group of indicators, which is associated with the organization of processes for achieving sustainable development by ensuring energy efficiency and environmental friendliness of industrial facilities, including through effective enterprise management.

At the same time, there are also known difficulties in the construction of point-rating assessments, which the authors, introducing into discussion issues for discussion, want to avoid. The most common disadvantages include: redundancy of criteria (especially in the case when there is a partial duplication of criteria), which increases the complexity of work with the evaluation system and the subjective nature of the scoring of indicators, which depends on the level of competence of experts. Let us single out several positions 
for discussion related to the implementation of a point-rating assessment in assessing the energy efficiency of industrial facilities. These include:

- determination of criteria and scales (ranks) for evaluating indicators;

- determination of intervals (standardization) of permissible values;

- interpretation of the data obtained to make a decision regarding the evaluated object.

The simplest and most common method of constructing a rating scale, used in all areas of knowledge, is the method of paired comparisons-the assessment and choice of solutions, widely used in expert assessments when it is necessary to prioritize in the process of any activity or ranking of various objects [46]. To rank according to the importance of indicators for assessing the energy-efficiency of industrial facilities in each group, it is advisable to use the analysis of hierarchies by Thomas Saaty, which includes the following stages:

1. Isolation of the problem and determination of the purpose of the assessment.

2. Determination of the main criteria and alternatives for the assessment.

3. Building a hierarchy: a tree from a goal through criteria to alternatives.

4. Construction of a matrix of "pairwise comparisons" of criteria by purpose and alternatives by criteria.

5. Analysis of the resulting matrices.

6. Determination of the weights of alternatives according to the hierarchy system [46].

When compiling on a scale, you can use the existing practice, which involves the determination of the minimum allowable (threshold value) number of points for each indicator, group of indicators and the total amount of points. The threshold value of the final score can be adjusted according to the results of a survey of experts. The step of the interval value corresponding to a certain level of the energy efficiency class is proposed to be made equivalent. This practice is used when ranking objects of assessment in the systems of international "green" standards for real estate, which at the level of national rating systems in the field of energy efficient and green construction is coordinated by the International Committee on the so-called "green" buildings (Green Building Council) [47]. Therefore, the discussed issues of justifying the approach to rating the set of energy efficiency indicators of industrial facilities in order to ensure the uniformity of its measurements and interpretation of the data obtained are considered by the authors on the basis of a comparison of rating systems for assessing buildings according to international "green" standards. This makes it possible to form a judgment regarding the first two groups of indicators in the system of indicators of energy efficiency of industrial facilities proposed by the authors, which are associated with buildings and the production technologies implemented in them. Table 3 shows the structure of rating systems for assessing "green" standards in construction, for each section of which a set of indicators is used to determine the integral values obtained using the point-rating assessment.

Each section of the assessment includes several assessment indicators, normalized by quantitative values and qualitative characteristics, which are assessed on a scale in credits (points). After summing up the points received for each section, they are compared with the corresponding scaling system (Table 4). According to experts, this scaling system is characterized by the subjectivity of the distribution of final points between the assessment levels. It is also obvious that the set of sections, indicators and assessment criteria is determined in accordance with the individual priorities of expert organizations and national interests [48].

As you can see from Table 3, there is a scatter in the levels (ranks) of the scale in the compared standards. In practice, this leads to the fact that in the case of the "shortage" of several points to the threshold level, for example, in the LEED system, the company can apply for a certificate in the BREEAM system, which has more levels and a more flexible assessment system. For an enterprise, such an opportunity may be positive, but for a national or international monitoring system for data on the assessed objects, it is an obvious distortion of statistics. 
Table 3. Sections of the assessment of buildings according to international "green" standards.

\begin{tabular}{cccc}
\hline BREEAM [28] & LEED [27] & DGNB [29] & WELL [30] \\
\hline Energy & $\begin{array}{c}\text { Location and transport } \\
\text { accessibility }\end{array}$ & Environmental quality & Water \\
\hline Health and wellness & Sustainable objects & Economical quality & Air \\
\hline Innovation & Water use efficiency & Sociocultural and functional quality & Nutrition \\
\hline Land use & Energy and atmosphere & Technical quality (only for new objects) & Lighting \\
\hline Materials (edit) & Water use efficiency & Process quality & Physical activity \\
\hline Management & Indoor environmental quality & Location quality (new properties only) & Thermal comfort \\
\hline Pollution & Integrative process & & Noise control \\
\hline Transport & Innovations & & Materials (edit) \\
\hline Waste & Regional priorities & & Mental health \\
\hline Water & & & Community \\
\hline
\end{tabular}

Table 4. Scales of assessments in the systems of international "green" standards.

\begin{tabular}{|c|c|c|c|c|}
\hline & BREEAM & LEED & DGNB & WELL \\
\hline \multirow{5}{*}{ Ranking levels (scores) } & Pass (30-44) & Certified (40-49) & Bronze $\left(<35^{*}\right)$ & Silver (50-59) \\
\hline & Good (45-54) & Silver (50-59) & Silver (35-49) & Gold (60-79) \\
\hline & Very good (55-69) & Gold (60-79) & Gold (50-64) & Platinum $(\geq 80)$ \\
\hline & Excellent (70-84) & Platinum $(\geq 80)$ & Platinum $(\geq 65)$ & \\
\hline & Outstanding $(\geq 85)$ & & & \\
\hline
\end{tabular}

* For operated buildings.

Regarding the third group of indicators proposed based on the results of studies of the system for assessing the energy efficiency of an industrial facility, which is associated with the organization of processes for achieving sustainable development through measures to ensure energy efficiency and environmental friendliness, the authors used another material for comparison, which focuses on the activities of the enterprise management. Two methodological approaches were chosen for discussion in a similar area of assessmentthe determination of an integral point assessment of the sustainable economic condition of an enterprise and a comprehensive rating assessment of enterprises.

In the first of the considered methodological approaches, the integral point assessment of the sustainable economic state of the enterprise, the choice and justification of the criteria for this assessment and the establishment of restrictions on their change are presented in detail [49]. For this, for each indicator included in the corresponding classification group of assessment, either the upper and lower criteria boundaries of the level of the analyzed indicators are determined, or their optimal values, and for some indicators (for example, in terms of performance indicators), the trend of their change is taken as a criterion. Depending on the deviation of the achieved level of the indicator from the selected criterion, a point estimate is established according to the existing scale, which allows the company to be attributed to one of six classes of solvency. Thus, it can be noted that there is a principle of differentiation for choosing a scale (ranks) for assessing indicators, which takes into account their specific features.

In the second of the considered methodological approaches, the complex rating of enterprises is based on their comparison for each indicator of economic condition with a conditional reference enterprise that has the best results for all compared indicators, which is determined by actual data [50]. Thus, the basis for obtaining the rating of an enterprise is not the subjective assumptions of experts but the highest results of enterprises from 
the entire set of compared objects that have developed in real market competition. The benchmark for comparison is the most successful competitor, which has the best indicators. When implementing rating within the framework of this methodological approach, the main problem is finding a "reference" object.

Returning to the discussion of the point-rating assessment when making a decision regarding the assessed object when assessing the energy efficiency of an industrial facility, we can consider the following scale as a proposal: all assessment levels can be conditionally divided into "very high", "high", "medium", "low" and "critically low" energy efficiency. This can be used, for example, to develop various measures along the entire "vertical" energy efficiency management, from the state level to the enterprise level. In the case of establishing a high level of energy efficiency of the assessed object, the state can stimulate an enterprise that operates on the basis of the assessed industrial facility with tax incentives (for example, exemption from property tax) and other economic preferences. The most significant result for the enterprise itself is the identification of the potential for its even more successful development and the attraction of investments through "green" and "white" certificates. If a "low" and "critically low" level is identified, the enterprise needs to take urgent measures to bring the facility to a higher level of energy efficiency.

The considered disputable aspects in the study make it possible to determine its prospects associated with the development of the proposed new approach to assessing the energy efficiency of industrial facilities, namely, the need for:

- development of criteria and scales for assessing the energy efficiency of industrial facilities while ranking the indicators according to the degree of significance. Taking into account the analyzed experience, it is necessary to use the method of paired comparison of energy efficiency indicators with the involvement of experts;

- to define intervals (standardization) of permissible values of indicators. Studies have shown that it is advisable to determine the minimum threshold value for the sum of points, determined by the minimum permissible (according to regulatory documents and expert opinion) values for individual indicators and corresponding groups;

- to form recommendations for the interpretation of the data obtained when making decisions regarding the evaluated object. Based on the estimates obtained, the management of the enterprise will be able to make decisions on the choice of priority areas for increasing the level of energy efficiency of an industrial facility, create long-term and current plans containing organizational, methodological, technological and incentive measures to carry out the necessary energy-saving measures.

Thus, at the next stage of the study, it is planned, taking into account the debatable issues (the calculation basis for determining the indicators while using the possibilities of using data arrays of domestic and international standards), to rank the obtained values based on the pairwise comparison, and also to form a scale of energy efficiency levels of industrial facilities.

\section{Conclusions}

In the process of analyzing the subject area of the research, scientific and practical problems were identified and solved, which ensured the formation of a new approach to the system for assessing the energy efficiency of industrial facilities. The results obtained have been achieved through the use of a set of research methods, primarily based on materials from authoritative publications, the information provided on the official websites of state authorities in various countries, as well as a survey of the expert community.

The primary issue resolved in the study was the clarification of the category of "industrial facility", which is the object of the study. A common problem was identified-the lack of a unified approach to its definition in many countries, which was confirmed during a survey of representatives of the authoritative expert community. The proposed definition made it possible to concretize an industrial facility, generalizing the existing formulations, taking into account expert opinion, which made it possible to implement subsequent tasks. For an objective description of the factor space of the evaluated object of research, which 
determines the characteristics of its energy efficiency, specially formulated questions on this problem area were included in the expert survey conducted by the authors. The results of the survey made it possible to determine a set of factors affecting the energy efficiency of an industrial facility, as well as their distribution according to the degree of importance.

The most important result of the study was the formed system of indicators of energy efficiency of industrial facilities, formed into three groups: energy efficiency of a building, energy efficiency of technological processes, ensuring energy efficiency and environmental friendliness. The proposed system of indicators takes into account the accumulated practical experience in ensuring energy efficiency in many countries and the actual theoretical developments presented in scientific works, which made it possible to form a new approach to assessing the energy efficiency of an industrial facility and to develop methodological provisions for determining the assessment indicators. On the basis of these provisions, it is possible to conduct a point-rating assessment of the energy efficiency of an industrial facility using formalized procedures lined up by the authors in a certain sequence.

It is assumed that the developed system of indicators can be integrated into the national standards of countries and used in international rating systems for assessing the energy efficiency of industrial facilities. In the context of the transition of the world energy sector to the principles of sustainable development and low-carbon energy, the restrictions imposed by many countries on the volume of greenhouse emissions, a new approach to assessing the energy efficiency of industrial facilities will provide not only an effective tool for large-scale monitoring of the efficiency of energy-saving measures at industrial facilities of countries but also the implementation of the principles of sustainable development and ESG at the enterprises of the industrial sector of the economy.

The questions proposed by the authors for discussion determine the need for further research in the direction of developing a methodology for assessing energy efficiency indicators of industrial facilities. The expert assessment of energy saving and energy efficiency of industrial facilities proposed after discussions by the authors on the basis of a "reference" indicator for each group of types of economic activities of industrial facilities will provide an opportunity to classify industrial facilities by the level of energy efficiency and will allow unambiguous determination of the position of the facility in solving state-important problems, including in the field of subsidizing and lending measures to reduce energy intensity and optimize energy costs, to develop and implement alternative technologies with low energy intensity and will also create an important component of financial planning at the macro, meso and micro levels.

The applied significance of the results lies in solving the most important state tasks to ensure the implementation of energy conservation and energy efficiency policies by systematizing information on the energy characteristics of the key end consumers of energy resources, industrial facilities, and forming an objective idea of the potential for reducing the energy intensity of industrial products across the country.

Author Contributions: Conceptualization, N.V., T.M., N.T. and N.S. (Natalia Shchepkina); methodology, T.M., N.T. and N.S. (Natalia Shchepkina); validation N.V. and T.M.; formal analysis, N.T. and N.S. (Natalia Shchepkina); investigation, T.M., N.T. and N.S. (Natalia Shchepkina); writing-review and editing, N.V., N.S. (Natalia Solopova), N.T., N.S. (Natalia Shchepkina) and T.M.; visualization, N.T., N.S. (Natalia Shchepkina) and T.M.; supervision, N.V.; project administration, N.V. All authors have read and agreed to the published version of the manuscript.

Funding: This research was funded by RFBR, grant number 20-010-00754.

Data Availability Statement: Not applicable.

Conflicts of Interest: The authors declare no conflict of interest. 


\section{References}

1. Leonard, M.; Pisani-Ferry, J.; Shapiro, J.; Tagliapietra, S.; Wolff, G. The Geopolitics of the European Green Deal. Policy Contribution 04/2021, Bruegel. 2021. Available online: https://www.bruegel.org/wp-content/uploads/2021/02/PC-04-GrenDeal-2021-1.pdf (accessed on 1 December 2021).

2. Mitronova, T. The Fourth Energy Transition: Risks and Challenges for RussiaVedomosti. 2021. Available online: https://www. vedomosti.ru/opinion/articles/2021/01/31/856101-chetvertii-energoperehod (accessed on 1 December 2021).

3. Corporate Strategies for Carbon Neutrality. An Overview of the Climate Commitments of Global Companies. Available online: https:/ / www.economy.gov.ru/material/file/f55d57f8dcbb8ec195b1575e857610dc/03062021.pdf (accessed on 1 December 2021).

4. How Will ESG Performance Shape Your Future? Available online: https://www.ey.com/en_gl/assurance/how-will-esgperformance-shape-your-future (accessed on 1 December 2021).

5. ESG Investment. Available online: https://www.bwfa.com/esg-investing/ (accessed on 1 December 2021).

6. Statistical World Energy Yearbook 2021. Available online: https://yearbook.enerdata.net/total-energy/world-consumptionstatistics.html (accessed on 1 December 2021).

7. Directive 2012/27/EU of the European Parliament and of the Council of 25 October 2012 on Energy Efficiency, Amending Directives 2009/125/EC and 2010/30/EU and Repealing Directives 2004/8/EC and 2006/32/EC. Available online: https: / / eur-lex.europa.eu/legal-content/EN/TXT/?qid=1399375464230\&uri=CELEX:32012L0027 (accessed on 1 December 2021).

8. Directive (EU) 2018/844 of the European Parliament and of the Council of 30 May 2018 Amending Directive 2010/31/EU on the Energy Performance of Buildings and Directive 2012/27/EU on Energy Efficiency. Available online: https: / / eur-lex.europa.eu/ legal-content/EN/TXT/?uri=uriserv\%3AOJ.L_.2018.156.01.0075.01.ENG (accessed on 1 December 2021).

9. Proposal for a Directive of the European Parliament and Council on Energy Efficiency (Revised). Available online: https: / / eur-lex.europa.eu/legal-content/EN/TXT/?uri=CELEX:52021PC0558 (accessed on 1 December 2021).

10. Energy Efficiency Law. Available online: https://www.meti.go.jp/english/information/data/laws.html\#anre (accessed on 1 December 2021).

11. Gebäudeenergiegesetz (GEG). Available online: https://www.bgbl.de/xaver/bgbl/start.xav?startbk=Bundesanzeiger_BGBl\& bk=Bundesanzeiger_BGBl\&start=/ /*[@attr_id=\%27bgbl107s1519.pdf\%27]\#_bgbl_\%2F\%2F*\%5B\%40attr_id\%3D\%27bgbl120 s1728.pdf\%27\%5D_1611934877837 (accessed on 1 December 2021).

12. Law of the People's Republic of China “On Energy Saving". Available online: http://www.nea.gov.cn/2017-11/03/c_136725225. htm (accessed on 1 December 2021).

13. Foreign Electric Power Industry. Available online: https:/ /www.np-sr.ru/ru/market/cominfo/foreign/index.htm\#11 (accessed on 1 December 2021).

14. Law on Energy Saving and Energy Efficiency Improvement and on Amendments to Certain Legislative Acts of the Russian Federation: Federal Law No. 261-FZ от 23.11.2009 г. Available online: https:/ / docs.cntd.ru/document/9017693 (accessed on 1 December 2021).

15. CIS Electric Power Council. Anniversary Publication of the Summary Report on Key Issues of Ecology, Energy Efficiency and RES in the Electric Power Industry of the CIS Participants. Available online: http://energo-cis.ru/wyswyg/file/57-Moscow\%20 2020/After\%20SUP / 17.11.2020\%20\%D0\%AE\%D0\%A1\%D0\%9E\%D1\%81\%20\%D1\%83\%D1\%87\%D0\%B5\%D1\%82\%D0\%BE\% D0\%BC\%20\%D0\%BF\%D1\%80-\%D0\%BA\%20\%D0\%9F\%D0\%9D\%D0\%90_\%D0\%9F\%D0\%B5\%D1\%82\%D1\%80\%D0\%BE\%D0 $\%$ B2\%D0\%B0.pdf (accessed on 1 December 2021).

16. Energy Policy Act (EPAct). The Energy Policy Act (EPAct) of 2005 (P.L. 109-58). 2005. Available online: https:/ /www.ferc.gov / enforcement/enforce-res/EPAct2005.pdf (accessed on 1 December 2021).

17. Electricity Regulation in South Korea. Available online: https:/ /www.lexology.com/library / detail.aspx?g=4a7f6594-b6b4-4249a928-a0e02ed683e5 (accessed on 1 December 2021).

18. The Official Website of the Building Energy Codes Program (BECP). Available online: https://www.energycodes.gov / (accessed on 1 December 2021).

19. The Official Website of the Energy Star Program. Available online: https://www.energystar.gov/about/origins_mission/energy_ star_numbers (accessed on 1 December 2021).

20. The Official Website of the State Energy Program (SEP). Available online: https://www.energy.gov/eere/wipo/state-energyprogram (accessed on 1 December 2021).

21. The Official Website of the Weatherization Assistance Program. Available online: https://nascsp.org/wap/ (accessed on 1 December 2021).

22. Japanese Programs. Energy Policy of Japan Magyar Tudományos Journal № 40. 2020. Available online: https://cyberleninka.ru/ article/n/energeticheskaya-politika-yaponii/viewer (accessed on 1 December 2021).

23. Japanese Programs. Podoba Energy Strategy and Green Energy Transition in Japan. Available online: https://cyberleninka.ru/ article/n/energeticheskaya-strategiya-i-perehod-k-zelyonoy-energetike-v-yaponii/viewer (accessed on 1 December 2021).

24. PD CEN ISO/TR 52000-2: 2017 Energy Performance of Buildings—Indicators, Requirements, Ratings and Certifications-Part 2: Explanation and Rationale for ISO 52003-1. Available online: https://www.iso.org/obp/ui/\#iso:std:iso:tr:52000:-2:ed-1:v1:en (accessed on 1 December 2021).

25. ISO 50001:2018 Energy Management Standard. Available online: https://www.iso.org/standard/69426.html (accessed on 1 December 2021). 
26. Standard ANSI/ASHRAE/IES 90.1-2019_Energy Standard for Buildings, Excluding Low-Rise Residential Buildings. Available online: https: / / www.ashrae.org/technical-resources/bookstore/standard-90-1 (accessed on 1 December 2021).

27. LEED. Available online: http:/ /leed.usgbc.org/leed.html (accessed on 1 December 2021).

28. BREEAM. Available online: https://www.breeam.com/ (accessed on 1 December 2021).

29. DGNB. Available online: https://www.dgnb-system.de/en/system/ (accessed on 1 December 2021).

30. WELL. Available online: https:/ / www.wellcertified.com/ (accessed on 1 December 2021).

31. ISO 52000-1:2017 Energy Performance of Buildings-EPB Overall Assessment-Part 1: General Framework and Procedures. Available online: https:/ /www.iso.org/standard/65601.html (accessed on 1 December 2021).

32. Standard for the Design of High-Performance Green Buildings Except Low-Rise Residential Buildings. Available online: https:/ / www.ashrae.org/file\%20library/technical\%20resources/standards\%20and\%20guidelines/standards\%20addenda/18 9_1_2020_ax_20210126.pdf (accessed on 1 December 2021).

33. International Green Construction Code (IGCC). Available online: https://www.ashrae.org/file\%20library/technical\%20 resources/bookstore/2018-igcc_preview_1102.pdf (accessed on 1 December 2021).

34. Existing Energy Certification Systems for Buildings Around the World. UNDP/GEF Project "Improving Energy Efficiency in the Housing Construction Sector of Turkmenistan" Ashhadab. 2016. Available online: https://docviewer.yandex.ru/view/ 0/?*=TSwcSs3CZ\%2B5\%2B6LLNw2GdSw1vwjR7InVybCI6Imh0dHBzOi8vd3d3LnVuZHAub3JnL2NvbnRlbnQvZGFtL3 R1cmttZW5pc3Rhbi9kb2NzL2xhdGVzdC1yZXBvcnRzL1dFQ19zeXN0ZW1zJTIwb2Y1MjBlbmVyZ3klMjBjZXJ0aWZpY2F0 ZXMlMjBvZiUyMGJ1aW (accessed on 1 December 2021).

35. Comparative Overview of Energy Efficiency Standards and Technologies in Buildings in the United Nations Economic Commission for Europe Region. Geneva. 2018. Available online: https://unece.org/fileadmin/DAM/hlm/Meetings/2018/09_05-07_St. _Petersburg/EE_Standards_in_Buildings_full_version.ENG.pdf (accessed on 1 December 2021).

36. ISO 52003-1:2017 Energy Performance of Buildings-Indicators, Requirements, Ratings and Certificates_Part 1: General Aspects and Application to the Overall Energy Performance. Available online: https://www.iso.org/standard/65662.html (accessed on 1 December 2021).

37. ISO/TR 52003-2:2017 Energy Performance of Buildings-Indicators, Requirements, Ratings and Certificates—Part 2: Explanation and Justification of ISO 52003-1. Available online: https:/ / www.iso.org/standard/65661.html (accessed on 1 December 2021).

38. Methodology for Determining (Calculating) the Energy Efficiency Classes of Apartment Buildings. Available online: https: //sro150.ru/metodiki/1034-opredelenie-raschet-klassov-energeticheskoj-effektivnosti-mnogokvartirnykh-domov (accessed on 1 December 2021).

39. Tusnin, V.M. Architecture of Civil and Industrial Buildings: Textbook; ASV Publishing House: Moscow, Russia, 2016; 328p.

40. Fisenko, A.A.; Basse, M.E. Architecture and Modern Information Technologies. -№ 1 (19). 2012. Available online: http: // marhi.ru/AMIT/2013/2kvart13/basse/abstract.php (accessed on 1 December 2021).

41. Order of the Ministry of Regional Development of Russia Dated 5 July 2011 No. 320 "On the Approval of the Set of Rules" Ensuring Anti-Terrorist Security of Buildings and Structures; General Design Requirements "(together with SP 132.13330.2011. Set of Rules; Ensuring Anti-Terrorist Protection of Buildings and Structures; General Design Requirements)". Available online: https: //www.economy.gov.ru/material/dokumenty/prikaz_minekonomrazvitiya_rossii_ot_29_iyulya_2019_g_468.html (accessed on 1 December 2021).

42. Order of the Federal Agency for Technical Regulation and Metrology Dated 19 December 2017 No. 2031-st “On Approval of the National Standard of the Russian Federation GOST R 58033-2017" Buildings and Structures. Dictionary, Part 1. General Terms. Available online: https:/ / docs.cntd.ru/document/556324274 (accessed on 1 December 2021).

43. Order of the Federal Agency for Technical Regulation and Metrology Dated 26 October 2016 No. 1519-st “On Approval of the National Standard of the Russian Federation GOST R 56828.15-2016" Best Available Technologies. Terms and Definitions. Available online: https:/ / docs.cntd.ru/document/456028927?marker (accessed on 1 December 2021).

44. Law "On the Industrial Policy of the City of Moscow" No. 55 Dated 7 October 2015. Available online: https://docs.cntd.ru/ document/537981669 (accessed on 1 December 2021).

45. Order of the Ministry of Construction, Housing and Communal Services of the Russian Federation of 17 September 2019 No. 544/pr “On approval of SP 18.13330.2019" Production Facilities. Planning Organization of the Land Plot "(SNiP II-89-80" General Plans of Industrial Enterprises)". Available online: https:/ / docs.cntd.ru/document/564407614? marker=7D20K3 (accessed on 1 December 2021).

46. Thomas, L.S. Decision Making with the Analytic Hierarchy Process. Int. J. Serv. Sci. 2008, 1, 83-98. Available online: https://web. archive.org/web/20170918192816/http:/ / www.colorado.edu/geography/leyk/geog_5113/readings/saaty_2008.pdf (accessed on 1 December 2021).

47. World Green Building Council (WorldGBC). Available online: https:/ /www.worldgbc.org/ (accessed on 1 December 2021).

48. Tabunshchikov, Y.A.; Granev, V.V.; Naumov, A.L. Rating System for Assessing the Quality of Buildings. AVOK No. 6'2010/Indoor Microclimate. Available online: https:/ / www.abok.ru/for_spec/articles.php?nid=4690 (accessed on 1 December 2021). 
49. Nikiforova, N.A.; Dontsova, L.V.; Dontsov, E.V. Data Mining in Modeling the Financial Condition of Enterprises. Available online: https:/ / www.nifi.ru/images/FILES/Journal/Archive/2011/2/statii/2011_02_01_.pdf (accessed on 1 December 2021).

50. Pchelintsev, A.D.; Pchelintsev, V.A. Methods for Determining Comparative Rating Economic State of Industrial Enterprises. Bull. Nizhny Novgorod Univ. 2010, 3, 583-593. Available online: http:/ /www.unn.ru/pages/e-library/vestnik/99999999_West_20 10_3(2)/37.pdf (accessed on 1 December 2021). 